\title{
Study on prevalence of hepatitis B in pregnant women and its effect on maternal and fetal outcome at tertiary care centre
}

\author{
Sunita Mishra*, Priyali Purandare, Ratna Thakur, Shweta Agrawal, Madhuri Alwani
}

\begin{abstract}
Department of Obstetrics and Gynecology, Sri Aurobindo Medical College and Postgraduate Institute, Near Mr-10
\end{abstract} Crossing, Sanwer Road, Indore, Madhya Pradesh, India

Received: 19 April 2017

Accepted: 04 May 2017

*Correspondence:

Dr. Sunita Mishra,

E-mail: dr_sunitamishra_16@yahoo.co.in

Copyright: () the author(s), publisher and licensee Medip Academy. This is an open-access article distributed under the terms of the Creative Commons Attribution Non-Commercial License, which permits unrestricted non-commercial use, distribution, and reproduction in any medium, provided the original work is properly cited.

\begin{abstract}
Background: Hepatitis-B is caused by double stranded DNA virus. Prevalence of hepatitis B in pregnant woman worldwide is 2.5 to $1.5 \%$ whereas in India it is 2 to $7.7 \%$.

Methods: This is a retrospective study conducted at SAMC and PGI, Indore between January 2016 to December 2016. Hepatitis- B prevalence and outcome was assessed by doing routine screening of hepatitis B antigen in our indoor patients and finding out their maternal and fetal outcome.

Results: Total 3567 deliveries were conducted during study period, out of them 39 were diagnosed as $\mathrm{Hbs} \mathrm{Ag}$ positive pregnant patient; so, prevalence was found to be $1.09 \%$. out of these, $84.6 \%$ were booked cases, mode of delivery was vaginal in $66.67 \%$ cases, preterm Delivery was in $10.26 \%$ of cases, meconium stained liquor was found in $5.13 \%$ cases, maternal mortality was nil, perinatal mortality was found in $2.56 \%$ cases and $5.13 \%$ cases were admitted in NICU.

Conclusions: Screening of all pregnant women for HbsAg irrespective of risk factors will definitely help to know the correct prevalence and reduce the transmission of hepatitis B infection. Hepatitis B is a major public health problem in India and will continue to be until appropriate nationwide vaccination programs and other control measures are established.
\end{abstract}

Keywords: Hepatitis B surface antigen, Pregnant woman, Prevalence

\section{INTRODUCTION}

Hepatitis B infection is found worldwide but is some regions especially endemic in Asia and Africa. Prevalence of Hepatitis B in pregnant women worldwide is 02.5 to $1.5 \%$ whereas in India it is 0.2 to $7.7 \% .^{1}$ Hepatitis B is caused by double stranded DNA virus belonging to hepadna viridae family. It leads to acute hepatitis and may also have serious complications like acute and chronic hepatitis, cirrhosis and hepatocellular carcinoma. ${ }^{2,3}$ The genome of HBV has four open reading frames that encode the four major proteins. Major products of these are surface protein (HBsAg), envelop protein $(\mathrm{HBe} \mathrm{Ag})$, core protein $(\mathrm{HbcAg})$, DNA polymerase and X protein. After a person is infected with $\mathrm{HBV}$, the first virological marker detected in serum is HBsAg which precedes elevation of serum transaminases and clinical symptoms. It remains detectable during entire icteric or symptomatic phase of acute hepatitis B and beyond. Hepatitis B infection is transmitted through blood, blood products, sexual contacts there is infrequent transplacental transmission of virus to the fetus. Vertical transmission of infection is mainly in the peripartum period with infected vaginal secretions and breast milk. ${ }^{4}$ Babies should be active immunized and passive immunization shortly after birth with Hepatitis B immunoglobulin and 3 doses of Hepatitis B recombinant 
vaccine. High risk women should be given vaccination during pregnancy.

Mostly HBV infection during pregnancy are asymptomatic and diagnosed during routine antenatal screening (ACOG-2007). ${ }^{5,6}$ There is no evidence to suggest that caesarean sections lower the risk. (ACOG2007)..$^{5}$

Hepatitis B virus is relatively stable in environment. It can remain viable for up to 7 days on surfaces at room temperature, and therefore, potentially infective, even if there is no visible blood. Any blood spills, should be cleaned using 1:10 dilution of one part house hold bleach to 10 parts of water for disinfecting the area. Gloves should be used when cleaning up any blood spill. It can co-exist with HIV infection. Health personal, homosexual, hemophiliacs, intra venous drug abusers are particularly prove to the hepatitis B infection.

\section{METHODS}

The present study is a retrospective study which included 39 cases of hepatitis B with pregnancy admitted in the department of Obstetrics and Gynaecology, SAMC and PGI, Indore, India between January 16 to December 16 . Total delivery conducted during this period was 3567 and all of them were included in the study. Case Records were obtained from the medical record department of our institute; all details of the patient were noted till they discharged from the hospital. The results were analyzed based on the master chart prepared. Ethical committee clearance was taken.

\section{Inclusion criteria}

All pregnant patients admitted in our antenatal ward with HbsAg positive by hepacard method and confirmed by ELISA.

\section{Exclusion criteria}

All Patients who were screened to be HBsAg +ve by Hepacard but not confirmed by ELISA.

\section{RESULTS}

Out of 3567 admitted patients between January 2016 to December 2016, total number of $\mathrm{HBs} \mathrm{Ag}+$ ve cases were 39. So, the prevalence of $\mathrm{HBs} \mathrm{Ag}+$ ve cases were $1.09 \%$ amongst indoor antenatal cases. Out of total 39 cases, 33 $(84.6 \%)$ were booked in our institute while 6 cases $(15.38 \%)$ were unbooked. Booked cases had an average of minimum 4 antenatal visits.

Mode of delivery was vaginal in 26 cases $(66.67 \%)$ whereas lower segment cesarean section was done in 13 cases $(33.33 \%)$ out of total 39 cases. Indication for lower segment cesarean section were for obstetrics indications only. Maternal Mortality was nil in the period of observation in HbsAg positive cases. Preterm Delivery was $4(10.26 \%)$ out of total 39 deliveries. Meconicum stained liquor was found in 2 cases $(5.13 \%)$ out of total 39 cases. Perinatal Mortality was found in only 1 case $(2.56 \%)$ and NICU admission 2 cases $(5.13 \%)$ out of 39 were admitted in NICU. All patients were later on shifted to mother side and discharged healthy.

\section{DISCUSSION}

The prevalence of hepatitis B infection varies in different parts of the world. Also, this prevalence varies from country to country, from one region to another region and from one group to another group in a country. ${ }^{8-10}$ Prevalence of hepatitis B in pregnant woman worldwide is 1.5 to $2.5 \%$ whereas in India it varies from 0.2 to $7.7 \%$. Prevalence of mean HBV carriers in India is $0.82 \%$ according to chatterjee et al. ${ }^{7}$

In our study prevalence rate is found to be $1.09 \%$ amongst indoor antenatal patients. It was found to be $0.5 \%$ in study of Rajshree et al whereas prevalence was found to be $1.56 \%$ in the study of aasan afzali et al. ${ }^{11,12}$ Thus, we find that our study is in accordance with the above studies.

Antenatal screening for hepatitis B is done in almost all the tertiary care centre as a routine practice. In our screening $84.6 \%$ were booked in our institute while $15.38 \%$ were unbooked cases. Our study is fairly comparable with the study of rajshree et al. ${ }^{11}$ Elective lower segment cesarean section does not increase the vertical transmission rate in $\mathrm{Hbs} \mathrm{Ag}$ carriers.

Preterm Delivery was found to be $10.26 \%$ which is in contrast with Tse KY et al. ${ }^{13}$ which suggest increased risk of preterm delivery with HBsAg carrier State.

In our study, perinatal mortality was found in $2.56 \%$ cases. $5.13 \%$ cases were admitted in NICU. In the study performed by wong et al perinatal out comes were comparable in HBs Ag carriers and non-carriers. ${ }^{14,15}$

\section{CONCLUSION}

Pregnant women who are HBs Ag positive are mostly asymptomatic. Screening of all pregnant women for HbsAg irrespective of risk factors will definitely help to know the correct prevalence and reduce the transmission of hepatitis B infection. Universal screening of antenatal cases and immunization with hepatitis $B$ vaccine of the community is definitely going to reduce the disease prevalence in future.

Hepatitis B is a major public health problem in India and will continue to be until appropriate nationwide vaccination programs and other control measures are established. Appropriate antenatal screening, intervention and immunoprophylaxis of the neonate is mandatory. 


\section{ACKNOWLEDGMENTS}

Authors would like to thanks Dr. Abhishek Singhai and Mr. Dheerap Singh for their support in manuscript preparation and support.

Funding: No funding sources

Conflict of interest: None declared

Ethical approval: The study was approved by the Institutional Ethics Committee

\section{REFERENCES}

1. Gukk HH, Majumdar PD, dhurinjiboy KR, Desai $\mathrm{HG}$, prevalence of Hepatitis $\mathrm{B}$, antigen in pregnant women and patients with liver disease. J Assoc. Physicians of India. 1995;43:247-48.

2. Kolawole OM, Wahab AA, Adekanle DA, Sibanda T, Okoh AI. Seroprevalence of hepatitis B surface antigenemia and its effects on hematological parameters in pregnant women in Osogbo, Nigeria. Virol J. 2012;9:317.

3. Jonas MM, Reddy RK, Demedina M, Sehiff ER. Hepatitis B infection in large municipal obstetric population: characterization and preventon of perinatal transmission Am $\mathrm{J}$ Gastroenterol. 1990;85:277.

4. Yang HI, Lu SN, Liaw YF, You SL, Sun CA, wang LY et al. Hepatitis $B$ e antigen and the risk of hepatocellular carcinoma. N Engl J Med. 2002;347:168-174.

5. American college of Obstetricians and Gynecologists ACOG Practice Bulletin No.86: Viral hepatitis in pregnancy. Obstet Gynecol. 110:941-956.

6. Sheila S. Hepatitis B. in; Diseases of the liver and biliary system $10^{\text {th }}$ Ed. Blackwell. 2001;272-6.

7. Chatterjee S, Ravishankar K, Chatterjee R, Narang A, Kinikar A. Hepatitis B Prevalence during pregnancy. Indian Pediatrics. 2009;46(11):1005-8.
8. André FE, Zuckerman AJ. Review: protective efficacy of hepatitis B vaccines in neonates. J Med Virol. 1994;44:144-51.

9. Lobste S, Faber R, Tillmann HL. Prevalence of hepatitis B among pregnant women and its impact on pregnancy and newborn complications at a tertiary hospital in the eastern part of Germany. Digestion. 2011;83:76-82.

10. Zali R, Mohammad K, Farhadi A, Masjedi MR, Zargar A and Nowroozi A. Epidemiology of hepatitis B in the IR of Iran. EMHJ. 1996;2(2):290-8.

11. Katke RD. The impact of maternal HbsAg carrier status on pregnancy outcomes: an institutional experience; Katke, Gynecol Obstet. (sunnyvale). 2015;5:5

12. Afzali H, Heravi M, Moravveji SA, Poorrahnama M. Prevalence of Hepatitis B Surface Antigen in Pregnant Women in Beheshti Hospital of Kashan, Isfahan; Iranian Red crescent medical journal' Rec. 2014;24.

13. Tse KY, Ho LF, Lao T. The impact of maternal HBsAg carrier status on pregnancy outcomes: a casecontrol study. J Hepatol. 2005;43:771-5.

14. Wong S, chan LY, Yu V, Ho L. Hepatitis B carrier and perinatal outcome in singleton pregnancy. Am J Perinatol. 2015;16:485-8.

15. Merat S, Malekzadeh R. Hepatitis B in Iran. Arc Irn Med J. 2003;4:192-201.

Cite this article as: Mishra S, Purandare $\mathrm{P}$, Thakur R, Agrawal S, Alwani M. Study on prevalance of hepatitis B in pregnant women and its effect on maternal and fetal outcome at tertiary care centre. Int J Reprod Contracept Obstet Gynecol 2017;6:223840. 